\title{
主として粘度および分子量の変化による歯科用印象材 としてのポリサルファイドゴムの硬化機構の検討
}

（第 8 報）考察および総括

\author{
安田周治 \\ 東京医科歯科大学歯学部第二理工学教室 (指導 : 神沢教授・東助教授)
}

(晊和 36 年 7 月 10 日受付)

\section{Discussions on the Setting Mechanism of Polysulfide Rubber as the Dental Impression Materials, Chiefly Viewing from the Variations of Viscosity and Molecular Weight}

(Part 8) Discussions and Summary

by

Shuji Yasuda

The second Department of Dental Technology, Tokyo Medical and Dental University

(Director: Prof. Yasuo Kanzawa, Assist Prof. Setuo Higashi)

\section{まえがき}

第 7 報1ままで著者はポリサルファイド系のゴ 么質印象材の縮合酸化剂として, 従来使用されて きた $\mathrm{PbO}_{2}$ と，東 ${ }^{2}$ の提案した $\mathrm{MnO}_{2} 3$ 部に $\mathrm{Pb}$ $\mathrm{O}_{2} 1$ 部の割合の混合酸化剂, および著者が新ら たに提案した ${ }^{3)} \mathrm{KMnO}_{4}$ などの 縮合能力を 検討 し，同時にこれらの酸化剤を用いた場合の充てん 剤, 可塑剤, 活性剤, 遅延剂, 環境温度などの影 響を, 粘度と分子量の変化から調查し, その研究 結果を基礎として $\mathrm{KMnO}_{4}$ を縮合酸化剂とする 新らしい歯科用印象材の試作品を調製1)してその

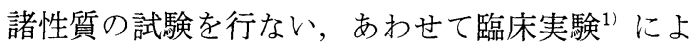
る検討を行なつたが，本報に扔いては粘度と分子 量の変化を追及寸ることによつて明らかになつた 第 1 報から第 7 報1334-8) までの諸結果に基づいて ポリサルファイドの硬化機構の総括的な考察を行 ないたい。

I 多硫化物系合成ゴムの構造について
多くの合成ゴム類はジェン類またはビニル重合 体であるが，多硫化物系合成ゴムと珪素ゴムはこ れらとはまつたく化学構造を異にし，独特の構造 を持つものと考えられる。

珪素ゴムの歴史は新らしいが，多硫化物系合成 ゴムは 1840 年に Löwig および Weidmann" に より，酒精カリと二硫化エタンとの反応により $\left(\mathrm{C}_{2} \mathrm{H}_{4} \mathrm{~S}\right) \mathrm{n}$ の化合物をえ，さらに多硫化力リとお なじく反応させて種々のゴム状物質を合成したの に始まり，1927 年に J.C. Patrick ${ }^{10)}$ がゴム類似 の可塑性物質の製法についてはじめて特許をえ, これとほとんど同時にスイスの Jean $\mathrm{Baer}^{11}$ が多 種のハロゲン化炭化水素を多硫化アルカリと反応 させて同様な特許をえている。1931 年に Thiokol Corp. により Thiokol という商品名で製造さ れはじめ ${ }^{12)}$ ，その他ドイッの I. G. 社イギリスの Dunlop-Rubbr Ltd. やカナダの Naugatuk Chemical Ltd. などで製造されたが，現在では Thiokol Corp. が主な製造会社である。 
多硫化系合成ゴムの製法には種々な方法が考え られるが，その多く沖両端に八ロゲン基（一般に Cl）を有する有機八ロゲン化物と多硫化アルカリ を縮合させる方法である。いわゆる“チオコー ル”は次のように縮合させて造られる。

$\mathrm{Na}_{2} \mathrm{~S}_{4}+\mathrm{nClCH}_{2} \cdot \mathrm{CH}_{2} \mathrm{Cl} \rightarrow\left(-\mathrm{CH}_{2}-\mathrm{CH}_{2}-\mathrm{S}_{4}-\right)$ $\mathrm{n}+2 \mathrm{NaCl}$

Patrick $^{13)}$ は $\left(\mathrm{CH}_{2}-\mathrm{CH}_{2}-\mathrm{S}_{2}\right) \mathrm{n}$ を還元分解し て, $\mathrm{HS}-\mathrm{CH}_{2}-\mathrm{CH}_{2}-\mathrm{SH}$ をえ, また $\mathrm{HS}-\mathrm{CH}_{2}$ - $\mathrm{CH}_{2}-\mathrm{SH}$ を酸化して $\left(\mathrm{CH}_{2} \cdot \mathrm{CH}_{2}-\mathrm{S}_{2}\right)$ を得たこ とから，二硫化ゴムは $(\mathrm{R}-\mathrm{S}-\mathrm{S})$ の単位分子 が反覆したものであることを明らかにしたが，四 硫化ゴムについては（R-S $-\mathrm{S}-\mathrm{S}-\mathrm{S}-\mathrm{R}$

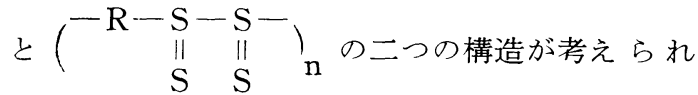
るために,

(一- $\left.\mathrm{CH}_{2}-\mathrm{CH}_{2}-\mathrm{S}_{4}-\right)$ n (Thiokol A) を苛性ソ 一ダで処理して二硫化物をえ,さらに還元してジ チオールをえたことから, $\left(\begin{array}{rr}\mathrm{R}-\mathrm{S}-\mathrm{S}-\mathrm{S} \\ \mathrm{H} & \| \\ \mathrm{S} & \mathrm{S}\end{array}\right)_{\mathrm{n}}$ の構造であると考えた。

また J. R. Katz ${ }^{14)}$ はX線回折より $\left(-\mathrm{CH}_{2} \cdot \mathrm{CH}_{2}\right.$ - $\mathrm{S}_{4}$ 一) $\mathrm{n}$ にたいし, 繊維周期 $8.8 \pm 0.03 \AA$ ，（一 $\mathrm{CH}_{2} \cdot \mathrm{CH}_{2} \cdot \mathrm{S}_{2}$ 一) n にたいし, 瀻維周期 $8.8 \pm 0.05$ 丹̊結果をえ，図165のような構造を考えた。

なお Tuller ${ }^{15}$ は Patrick, Katz らの構造に改良 を加えて下図のような構造を考えた。

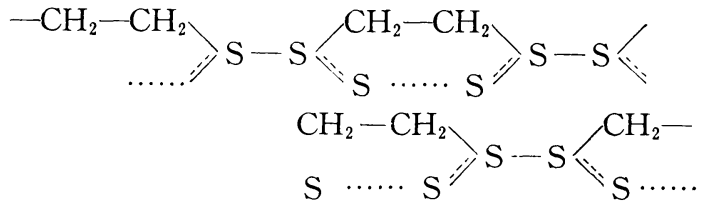

上述のように化学実験によつては側鎖にいおう の結合した状態が多く考えられたが，最近 J. Donohne および Schomaker ${ }^{16)} の$ dimethyltrisulfide にたいする電子線回折による研究, J. E. Beer および M. Carmack ${ }^{17)} の$ Alkyl polysulfides にた いする紫外線吸収スペクトル，おなじく紫外線吸 収スペクトルによる H.P. Koch ${ }^{18)}$ の研究, I.M. Dauson および J. M. Robertson のX線的研究等 はす心゙て直鎖状にい抢うが結合している構造を主
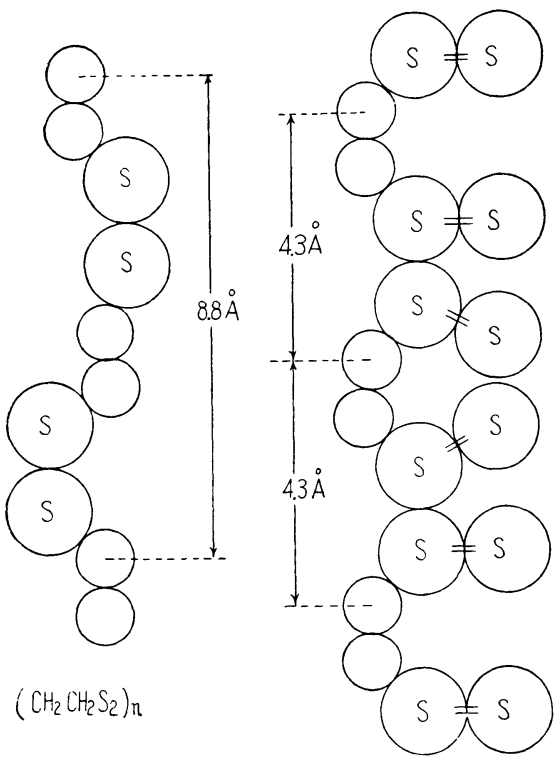

$\left(\mathrm{CH}_{2} \mathrm{CH}_{2} \mathrm{~S}_{4}^{-}\right)_{n}$

図 165 四硫化物の構造図

張している。

また箕浦 ${ }^{199}$ は多硫化物系合成ゴムのモデルとし て低分子の有機多硫化物を合成し，その紫外線吸

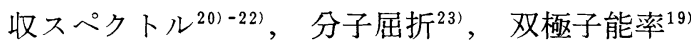
の測定より，これら多硫化物のいおうは直鎖状に 並んでいることを明らかにした。

著者は前記のような多数の報告を参照して検討 した結果，多硫化物系合成ゴムのい扝うの結合様 式は直鎖状であると考え，本研究に使用した Thiokol 社製品の液状の二硫化ゴム LP-205（平 均分子量約 1000 , 比重 1.27 , 未端基 $\mathrm{SH}$ ), およ び LP-2 (平均分子量約 4000 , 比重 1.27 , 未端 基 $\mathrm{SH}$ )のいおうの結合様式 は直鎖状であると考 えて, その硬化機構の研究を行なつた。

II 分子量の上昇から硬化機構の検討

本研究において著者は粘度の上早を測定し，そ の測定值から分子量を求めて分子量一時間曲線を 描き ${ }^{4)}$ ，各種酸化剤のポリサルファイドに対する 縮合能力を検討したが，分子量一時間曲線はとり もなおさず反応速度曲線とも考えられ，反応速度 曲線を求める場合には反応槽の温度を一定に保つ 
て，粘度または分子量の上昇を測定するか，また は $\mathrm{k}=\mathrm{Ae}^{-\Delta \mathrm{E} / \mathrm{RT}}$ 式 $^{24)}$ (ただし $\mathrm{k}$ : 反応速度定数, $\mathrm{E}$ ：活性化エネルギー, R： gas const（ボルツマ ン定数), $\mathrm{T}$ ：絶対温度, $\mathrm{A}$ ：Arrhenius factor) によつて反応速度の温度補正を行なうかのいずれ かの方法を採るのが常識であるが，ポリサルファ イドは熱の不良導体であるために，縮合による発 熱を急速に冷却し, 反応槽中の温度を一定に保つ ことは非常に困難であり，その上ポリサルファイ ドの反応速度定数はいまだに決定されていないた めに，上記の反応速度式による温度補正を行なう こともできないのである。

東 ${ }^{2)}$ は種々の酸化剂をポリサルファイドに作用 させた場合の内部温度の変化を測定し，温度時間 曲線の形から酸化剤の縮合能力を帰納的に知つ た。

著者は東の採用した研究方法を参照して, 次の 研究方法を採つた。すなわち各種酸化剂をポリサ ルファイドに作用させた場合は，いずれも発熱反 応であるため温度の上昇が抢こるが，温度の上昇 は分子量の上昇にほぼ比例するものと考えられる から，室温を一定にした場合には，各酸化㓮はそ れぞれの縮合能力に応じた分子量一時間曲線を描 くはずであり，これを検討することによつてほぼ 正確にそれぞれの縮合能力を比較することができ るものと考えた。

1.オゾンを縮合酸化剂とした場合

一般に各種の酸化剂を用いてポリサルファイド を硬化させているが，純粋の酸素またはオゾンの みで硬化できるか否かを調べて見た。

\section{実験の方法}

分子量約 1000 のポリサルファイドに等量（重 量）のキシロールを加えて溶解させ，靦找装置を つけてよく攪汼しながら，これにオン゙ン発生装置 からオゾンを通じ， 1 時間後， 6 時間後，12 時 間後にそれぞれに蒸発しただけのキシロールを補

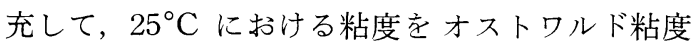
計 No 3 を用いて測定した。

また分子量約 4000 のポリサルファイドに等量

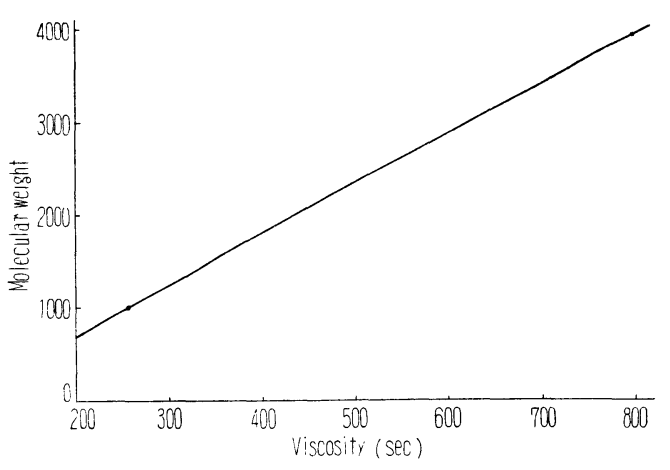

図 166 オゾンを縮合酸化剤とした場合の 粘度一分子量曲線

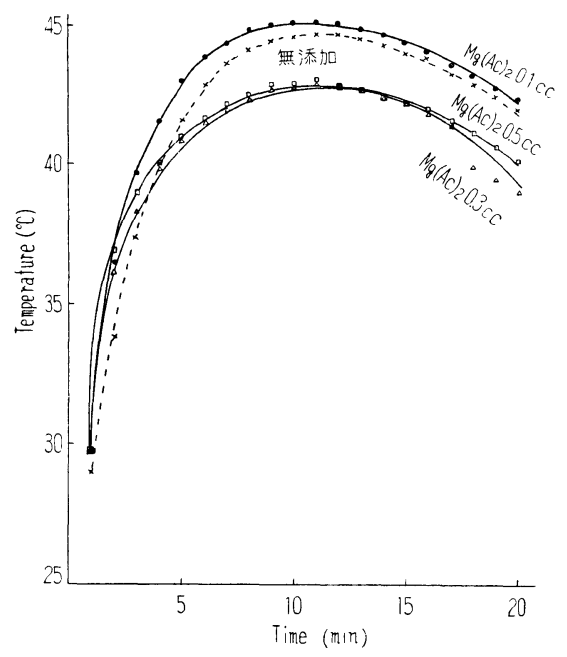

困 167 酢酸マグネシウムの影響

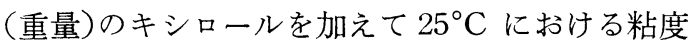
を測定し， X 軸に粘度(秒数)をとり，Y軸に分子 量をとつて, 分子量約 1000 の場合の粘度との二 点を直線で結んで図 166 を作製し，これより各粘 度(秒数)に対応する分子量を求めた。

\section{実験の結果}

この実験の結果を表 78 に示す。この実験の結 果からオゾンはポリサルファイドに対して縮合能 力を有することが明らかになり，単独にオゾンま たは活性酸素を作用させただけでも縮合反応が行 なわれることが明らかになつた。

2. $\mathrm{Pb} \mathrm{O}_{2}$ を縮合酸化剤とした場合 
表 78 オゾンを縮合酸化㓮とした場合の 粘度と分子量の変化

\begin{tabular}{c|c|c}
\hline \hline Time (hr) & Viscosity (sec) & molecular weight \\
\hline 0 & 255 & 1000 \\
0 & 792 & 4000 \\
\hline 1 & 258 & 1030 \\
6 & 311 & 1300 \\
12 & 460 & 2150
\end{tabular}

Thiokol LP-205. molecular-weight 1000 を使用

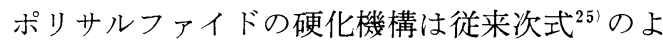
うに考えられている。

(1) $\mathrm{R}-\mathrm{SH}+\mathrm{PbO}_{2} \rightarrow \mathrm{R}-\mathrm{S}-\mathrm{S}-\mathrm{R}+\mathrm{PbO}+$ $\mathrm{H}_{2} \mathrm{O}$

(2) $\mathrm{R}-\mathrm{SH}+\mathrm{PbO}_{2} \rightarrow \mathrm{R}-\mathrm{S}-\mathrm{Pb}-\mathrm{S}-\mathrm{R}+$ $\mathrm{H}_{2} \mathrm{O}$

（3） R-SH+有機過酸化物 $\rightarrow \mathrm{R}-\mathrm{S}-\mathrm{S}-\mathrm{R}$ $+\mathrm{H}_{2} \mathrm{O}$

このように最初の段階は二つのモノマーの間の 分子間エステル化によつて二量体が生成し，続い て二量体モノマーと反応して三量体をつくるか, または二量体が他の二量体と反応して四量体を造 る反応がつぎつぎに起る。これらの多量体はまた 順次モノマー，二量体，三量体…とつぎつぎに 反応して行くものである。

上述の式( 2 )において縮合生成物中に $\mathrm{Pb}$ が結 合しているか否かを確かめるために次の実験を行 なつた。

\section{実験}

分子量約 1000 のポリサルファイド $85 \mathrm{~g}$ に, $\mathrm{PbO}_{2} 15 \mathrm{~g}$ を混合し，練和開始より 10 分毎に 60 分まで, 反応進行中の試料を約 $2 \mathrm{~g}$ ずつ採取し, ベンゾール $100 \mathrm{cc}$ ずつを扮のおのに加えて，完 全に反応生成物を溶解させた後濾過し，その濾液 からベンゾールを追出した後，試料をルッボに入 れて燃焼させ，ルツボに硝酸を加えて残留物を溶 解し, 硝酸溶液中に $\mathrm{Pb}$ が存在しているか否か

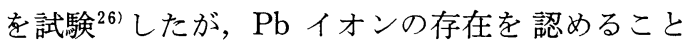
はできなかつた。

この実験の結果から式( 2)の反応生成物中には
$\mathrm{Pb}$ は結合していないことが明らかになつた。ま た第 2 報5ににおいて $\mathrm{PbO}$ を縮合剤として使つた 場合に, $\mathrm{PbO}$ は相当な縮合能力を持つことを報 告したが，この報告と上述の実験結果とを考察し た結果， $\mathrm{PbO}_{2}$ は $\mathrm{O}$ を放出して脱水縮合を行なう ほかに， $\mathrm{PbO}$ または $\mathrm{Pb}$ の形でポリサルファイ ドに触媒的に働らいて直鎖状に縮合させるものと 考えられる。

第 2 報5゙において $\mathrm{PbO}_{2}$ の縮合能力を分子量の 上昇から検討した結果, $\mathrm{PbO}_{2}$ は時間の経過とと もに縮合能力が頭打ちすることが明らかになつた が，この原因は $\mathrm{PbO}_{2}$ は分解して $\mathrm{PbO}$ と $\mathrm{O}$ とな

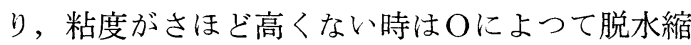
合が行なわれると同時に，PbO が触媒として働 らくが粘度が高くなれば，PbO が触媒として働 らきにくくなり，単にOの脱水縮合のみが主とし て起るから縮合反応が頭打ちするのであると考え られる。

3. $\mathrm{MnO}_{2} 3$ 部と $\mathrm{PbO}_{2} 1$ 部の割合の混合酸化 剂の場合

第 3 報 ${ }^{6)}$ において著者は東 ${ }^{2)}$ の提案した $\mathrm{MnO}_{2}$ 3 部と $\mathrm{PbO}_{2} 1$ 部の割合の混合酸化剂の縮合能力 を分子量の上昇から検討した結果， $\mathrm{PbO}_{2}$ に比較 してはるかに強力であることが明らかになつた が，この原因が結合様式にも関連性があると推察 されるので，次の実験を行なつてその原因を追及 した。

\section{実験の方法}

分子量約 1000 のポリサルファイドに，縮合酸 化剤として， $\mathrm{PbO}_{2} 15 \%$ ，混合酸化剂 $\left(\mathrm{MnO}_{2} 3\right.$ 部： $\mathrm{PbO}_{2} 1$ 部) $30 \%$ および $\mathrm{KMnO}_{4} 10 \%$ を混 合した場合と， $\mathrm{PbO}_{2} 15 \%$ と混合酸化剂 $30 \%$ に それぞれいおうを $3 \%$ 添加した場合の 5 種類の試 料を調整し, 練和開始後 3 分, 6 分, 10 分, 12 分, 15 分, 20 分, 25 分, 30 分, 40 分, 50 分, 60 分経過ごとに反応進行中の試料約 $1 \mathrm{~g}$ ずつを 採取し，キシロール約 $15 \mathrm{cc}$ を入れた試験管にこ れを手早く投入してょく攪挥し，1昼夜放置して その溶解状態を検討した。 
表 79 溶 解 度

\begin{tabular}{|c|c|c|c|c|c|c|c|c|c|}
\hline 混合物 & 3 & 6 & 10 & 12 & 15 & 20 & 30 & 50 & 60 \\
\hline $\mathrm{PbO}_{2}$ & $\mathrm{~S}$ & - & $\mathrm{S}$ & 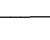 & - & $\mathrm{S}$ & S & $\mathrm{S}$ & $\mathrm{S}$ \\
\hline $\mathrm{PbO}_{2}+\mathrm{S}$ & $\mathrm{S}$ & - & $\mathrm{S}$ & 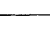 & 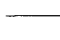 & $\mathrm{S}$ & $\mathrm{S}$ & S & $\mathrm{S}$ \\
\hline 混合酸化剂 & $\mathrm{S}$ & S & SiS & iS & iS & iS & 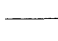 & 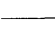 & \\
\hline 混合酸化剂 $+\mathrm{S}$ & $\mathrm{S}$ & iS & iS & iS & iS & iS & $\longrightarrow$ & 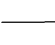 & - \\
\hline $\mathrm{KMnO}_{4}$ & SiS & $\mathrm{SiS}$ & is & iS & is & iS & 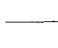 & $\ldots$ & 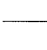 \\
\hline
\end{tabular}

S : soluble SiS : slightly insoluble

iS : insoluble

\section{実験の結果}

この実験の結果を表 79 に示す。表 79 の結果か ら, $\mathrm{PbO}_{2}$ と $\mathrm{PbO}_{2}$ にいおうを添加したものはい ずれもすべてキシロールに溶解し，混合酸化剤は 練和開始後 10 分で一部不溶性となり，12 分後に 完全に不溶性となつた。混合酸化剤にいおうを混 合した場合は 6 分で不溶性となり， $\mathrm{KMnO}_{4}$ は 3 分から一部不溶性となり，10分で完全に不溶性 となつた。この不溶化現象を一般に“ゲル点”と 称している。

ゲル点 ${ }^{27)}$ にいて

いわゆる “ゲル点” は高分子状態への進行中に 現われる重合あるいは縮合度のクニックと考えら れるもので，物質はこの点で急に粘稠な液体から 弾性ゲルに変化するのである。ゲル点前において は，すべての重合体は適当な溶媒に溶解し，また 熔融する。ゲル点を越えると熔融しても液状にな らず，また溶剤にもまつたく溶解しない。一方線 状構造の高分子物質は, その重縮合度に無関係に 常に適当な溶媒に溶解し，また熔融すれば液状に もなるのである。

このゲル化ならびにそれに伴なら不溶化現象 は，す心゙ての非線状重合反応において常に現われ るものであつて，これらの特性は高分子物質内に ある無限の大きさの三次元ないし空間網目構造の 束縛効果によるもので，これこそ多くの非線状構 造の高分子物体を線状のものから区別する効果的 な方法である。

一般に多官能性の分子が存在すると非常に大き
な化学構造をつくるようになり, それに対しては 無限網目構造というのが適当である。普通の分子 の大きさの標準からみれば抎がりは限りないとみ てよいから，無限網目といら言葉を使うのである が，これらの三次元的な網目構造は常にゲル化と いう現象の原因となるもので，たとえばビニール とジビニル共重合や，ゴムの加硫や，フェノール とホルムアルデヒドからできる熱硬化性樹脂の成 型や，塗料用油脂の乾燥の場合などによく見られ る現象である。

無限網目構造を持つ ${ }^{28)}{ }^{29}$ 縮合重合分子には，た くさんのまだ反応していない官能基が残つてい て，同じ分子の中の官能基の 1 対が反応を起すこ とがよくあり, その分子内反応が, 分子間の縮合 に比して相当の程度まで進むといらことは Kienle およびその協同研究者 ${ }^{30) 311}$ たちのグリセリンと二 塩基性酸との縮合の実験で示されている。

無限網目の生成過程において起る線状構造体分 子間での化学結合を, 通常これを架橋といい, ゴ ムの加硫はこの種の過程でもつとも著るしいもの で，いおうや促進剤などの作用によつて硫化物の 架橋ができるものと触勫されている。

Signer と Tovel ${ }^{32}$ はセルローズ誘導体におけ る水酸残基に塩化オキザリルを作用させてメチル セルローズをゲル化し，Jullander と Blom Sallin は ${ }^{33)}$ チタニウムとシリコンの 四塩化物が $>\mathrm{CH}$ 一 $\mathrm{O}-\stackrel{\mathrm{I}}{\mathrm{T}} \mathrm{i}-\mathrm{O}-\mathrm{CH}<0$ ように分子間で 水酸基を結 Cl

びつける作用を使つて, 硝酸セルローズに架橋を 
行ない，水酸基を持つている重合体はジイソシャ ナート (diisocyanate) で架橋させ, Fordyce と Ferry ${ }^{34)}$ はスチレン一無水マレイン共重合体をグ ライコールの作用で架橋した。

第 3 報 ${ }^{6}$ におおて混合酸化剂 $\left(\mathrm{MnO}_{2} 3\right.$ 部: $\mathrm{PbO}_{2}$ 1 部) $30 \%$ \% ポリサファイドに作用させた場合 には，練和開始後 10 分より粘度および分子量が 急速に上昇することが認められ，また $\mathrm{MO}_{2}$ （た だしMは 2 価または 4 価の金属）を縮合酸化剂と して用いた場合に考えられる硬化機構の一つで ある。

$$
2-\mathrm{RSH}+\mathrm{MO} \rightarrow \mathrm{R}-\mathrm{S}-\mathrm{M}-\mathrm{S}-\mathrm{R}+\mathrm{H}_{2} \mathrm{O}
$$

によつて生成が想像される金属メルカプチド結合 在持つ一 $\mathrm{R}-\mathrm{S}-\mathrm{M}-\mathrm{S}-\mathrm{R}$ 一は，加熱による か，少量のいおうを添加することによつて

$-\mathrm{R}-\mathrm{S}-\mathrm{M}-\mathrm{S}-\mathrm{R}-\mathrm{S} \rightarrow-\mathrm{R}-\mathrm{S}-\mathrm{S} \mathrm{R}$ $-+\mathrm{MS}$

のように二硫化物と MS になるという機構が 報 告 ${ }^{25}$ されており，また上述の実験において練和開 始後約 10 分でゲル化が起り始めることなどを検 討した結果，次のことがらが推察される。

すなわち混合酸化剂 $30 \%$ を作用させた場合は, はじめの約 10 分間は脱水縮合反応のみが起つて, 直鎖状の高分子物質が生成されるが，10 分以後 は脱水縮合反応の他に $\mathrm{MnO}$ よる架橋反応が起つ て網目構造になるため，急速に粘度および分子量 が増大するものと考えられ，次式のような機構を 考えて見た。

i $\quad 4 \mathrm{RSH}+2 \mathrm{MnO} \longrightarrow$

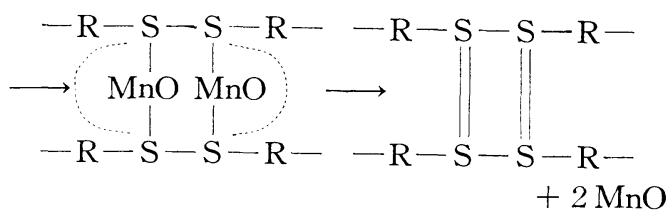

ii

$$
\begin{aligned}
4 \mathrm{RSH}+2 \mathrm{MnO} \rightarrow & -\mathrm{R}-\mathrm{S}--\mathrm{MnO}-\mathrm{S}-\mathrm{R}- \\
& -\mathrm{R}-\mathrm{S}-\mathrm{MnO}-\mathrm{S}--\mathrm{R}- \\
& -\mathrm{R}-\mathrm{S}-\mathrm{S}-\mathrm{R}- \\
& -\mathrm{R}-\mathrm{S}-\mathrm{S}-\mathrm{S}-\mathrm{R}-
\end{aligned}
$$

iii

$$
\begin{aligned}
4 \mathrm{RSH}+2 \mathrm{MnO} \rightarrow & -\mathrm{R}-\mathrm{S}-\mathrm{Mn}-\mathrm{S}-\mathrm{R}- \\
& -\mathrm{R}-\mathrm{S}-\mathrm{Mn}-\mathrm{S}-\mathrm{R}- \\
+2 \mathrm{H}_{2} \mathrm{O}+2 \mathrm{~S}-\mathrm{R}-\mathrm{S}-\mathrm{S}-\mathrm{R}- & \stackrel{\|}{\longrightarrow}-\mathrm{R}-\mathrm{S}-\mathrm{S}-\mathrm{R}-
\end{aligned}
$$

すなわち i, ii の場合は $\mathrm{MnO}$ が触媒の作用を ᄂ て $-\mathrm{R}-\mathrm{S}-\mathrm{S}-\mathrm{S}-\mathrm{R}$ iii の場合は少量の Sの添加によつてマンガンメ ルカプチド結合から Mn が MnSの形で脱出し, その時に $-\mathrm{R}-\mathrm{S}-\mathrm{S}-\mathrm{S}-\mathrm{R}-$ のような架橋を行な

\section{うものと推察される。}

4. $\mathrm{KMnO}_{4}$ を縮合酸化剂とした場合

第 6 報3において $\mathrm{KMnO}_{4} 10 \%$ をポリサルフ アイドに作用させた場合には，練和開始後 3 分で すでに粘度および分子量の急速な上昇が認めら れ, また表 79 から 3 分後からゲル化が始まるこ とを検討した結果次のことがらが推察される。

i $\mathrm{KMnO}_{4}$ が分解して活性酸素を発生して，ポ リサルファイドを脱水縮合させる。

ii その場合に生成した $\mathrm{H}_{2} \mathrm{O}$ と $\mathrm{KMnO}_{4}$ が反 応して次式の反応が起り,

$$
2 \mathrm{KMnO}_{4}+\mathrm{H}_{2} \mathrm{O} \rightarrow 2 \mathrm{KOH}+2 \mathrm{MnO}_{2}+30
$$

活性酸素は引き続いて脱水縮合を行ない， $\mathrm{KOH}$ は反応系をアルカリ性雲囲気にして縮合反応を促 進する。

iii $\mathrm{KMnO}_{4}$ が分解して生成した $\mathrm{MnO}_{2}$ は, 混合酸化剂中の $\mathrm{MnO}_{2}$ と同様に $\mathrm{MnO}$ とOに分 解し， $\mathrm{MnO}$ が触媒の作用を行なつて $-\mathrm{R}-\mathrm{S}-\mathrm{S}-\mathrm{R}-$ $-\mathrm{R}-\mathrm{S}-\mathrm{S}-\mathrm{R}$ -

に分子量を増大させるものと考えられる。

すなわち $\mathrm{KMnO}_{4}$ によるポリサルファイドの 縮合反忘は, 活性酸素による脱水縮合のほかに, $\mathrm{MnO}_{2}$ の生成による架橋効果に加えて, 強アル カリである $\mathrm{KOH}$ の促進作用が現われ，いつそう はげしく推進されるものと解釈される。

第 6 報 ${ }^{3)}$ において $\mathrm{KMnO}_{4}$ にいおうを混合し 
た場合に、、おうが酸化されて亜硫酸または硫酸 を生成してアルカリ性雲囲気をそこなう結果, 縮 合能力を低下させるものと推察したが， $\mathrm{pH}$ 測定 器を用いて次の実験を行なつてこの推察が正しい かどうかを確認してみた，

\section{実験の方法}

いおう $3 \%$ を混合した $\mathrm{KMnO}_{4}$ を縮合酸化剂 とする次の組成の歯科用印象材を作製した。

A凰：ポリサルファイド $72 \%, \mathrm{SiO}_{2} 15 \%$, 半水せつこう $10 \%$ ，い抢う $3 \%$ 。

B剤: $\mathrm{KMnO}_{4} 4 \%, \mathrm{SiO}_{2} 32 \%, \mathrm{ZnO} 32 \%$. D.B.P. $32 \%$ 。

練和開始後 20 秒ごとに反応中の試料約 $1 \mathrm{~g}$ を 採取し, 水 $10 \mathrm{cc}$ を入れた試験管中にただちにこ れを投入し, よく振つて $\mathrm{pH}$ 測定器でこの水溶 液の $\mathrm{pH}$ を測定した。

\section{実験の結果}

この実験の結果を表 80 に示す。表 80 によれば, 表 $80 \quad \mathrm{KMnO}_{4}$ にたいする $\mathrm{S}$ の影響

\begin{tabular}{c|c|c}
\hline $\begin{array}{c}\text { Sample } \\
\text { No. }\end{array}$ & Time (sec) & $\begin{array}{c}\text { Hydrogen ion } \\
\text { exponent }(\mathrm{pH})\end{array}$ \\
\hline 31 & 20 & 8.02 \\
32 & 40 & 6.20 \\
33 & 60 & 8.01 \\
34 & 80 & 6.55 \\
35 & 100 & 7.65 \\
36 & 120 & 8.28
\end{tabular}

練和開始 20 秒後は $\mathrm{pH}$ 約 8.02 であるが，40 秒 後に至り約 6.2 となつて微酸性を示し, 60 秒後 に微アルカリとなつて縮合反応が活発化するが, 80 秒後には $\mathrm{pH}$ は 6.55 の微酸性をふたび呈し, 以後はしだいにアルカリ性が強くなつて反応の急 上昇が認められ，第 6 報 ${ }^{3)}$ の仮説が正しいことが 証明された。

以上のことから $\mathrm{KMnO}_{4}$ は, 活性酸素による 脱水縮合と, $\mathrm{MnO}$ の触媒作用による

$$
-\mathrm{R}-\mathrm{S}-\mathrm{S}-\mathrm{S}-\text { のような架橋反応と, 分解生 }
$$

成物 $\mathrm{KOH}$ のアルカリ性䨌囲気構成による促進 作用の三者の綜合的な働らきによつて, 非常に強 力な縮合能力を発揮するものと考えられる。

III 充てん剤について

i カーボンは優れた充てん剤であるが，污染 性が強いため歯科用として做避けるべきである。

ii $\mathrm{SiO}_{2}$ は無難な充てん剂と考えられる。

iii 半水せつこうはわずかながら 縮合反応に活 性化作用を示すが，一応無難であると考えられ る。

iv $\mathrm{ZnS}$ を $10 \%$ \%し $15 \%$ 添加した場合に は, 縮合反応を促進する傾向が認められるから, A剂側への充てん剤として良好なものではないと 考えられる。

v $\mathrm{TiO}_{2}$ を $10 \%$ 以上添加すると, ある程度の 活性化作用を行ない縮合反応を助長するから，A 剤に混合する充てん剤としては不適当であるが， B剤に混合すれば良好であると考えられる。

\section{IV 可塑剂について}

i ジブチルフタレート(D.B.P.)を混合酸化剤に 配合した場合はひまし油に劣るが， $\mathrm{KMnO}_{4}$ には 最適である。な抢ジオクチルフタレート(D.O.P.) はポリサルファイドと共溶性がないから使用でき ない。

ii Monsanto HB-40 を混合酸化剂に配合した 場合は, D.B.P. と同程度の効果があるが, $\mathrm{KMnO}_{4}$ を使用する場合には不適当である。

iii ひまし油は混合酸化剤には最良の可塑剤で あるが， $\mathrm{KMnO}_{4}$ に配合した場合には，第 6 報 ${ }^{3)}$ に詳述したように，ひまし油の主成分であるリシ ノ一ル酸グリセリドが， $\mathrm{KMnO}_{4}$ によつて脱水さ れ共やく二結合を有するリノール酸グリセライド に変わり, $\mathrm{KMnO}_{4}$ の分解によつ生成した活成酸 素によつて重合し， $\mathrm{KMnO}_{4}$ の縮合能力を低下さ せるために，可塑剤として使用してはならない。

$\mathrm{V}$ 活性剤について

i いおうを混合酸化剤に混合した場合は, 添加 量 $2.4 \%$ 以下では縮合反応を遅らせ， $2.8 \%$ 以上 になると促進することを認めたが， $\mathrm{KMnO}_{4}$ に添 加した場合は本報 II に詳述したように，反応系を 
酸性雲囲気にして縮合反応を遅らせるために， $\mathrm{KMnO}_{4}$ と共用してはならない。しかしながらポ リサルファイド系ゴムの場合でも, その他のゴム と同様にいおうと配合するのが常識になつている ことが障害となつて, $\mathrm{KMnO}_{4}$ をポリサルファイ ドの縮合酸化剤として使用することを見落してい たものと考えられる。

ii $\mathrm{ZnO}$ を $10 \%$ 以上添加すると，わずかなが ら縮合反応を促進するが，有効な促進剤とは考え られない。

iii 酢酸マグネシウムは一般に促進剤と考えら れているが，第 5 報において混合酸化剂に添加し た場合に逆の傾向を示したので再検討して見た い。

\section{実験の方法}

分子量約 1000 のポリサルファイド $40 \mathrm{~g}$ に, 混 合酸化剤 $\left(\mathrm{PbO}_{2} 1\right.$ 部: $\mathrm{MnO}_{2} 3$ 部) $10 \mathrm{~g}$ を混合す る場合に，酢酸マグネシウム $20 \%$ 水溶液をそれ ぞれ $0.1 \mathrm{cc}, 0.3 \mathrm{cc}, 0.5 \mathrm{cc}$ 添加して温度上昇を 測定した。

\section{実験の結果}

実験の結果を表 81 に示す。表 81 の各項に対応 する温度一時間曲線を図 167 に示す。この実験の 結果から，酢酸マグネシウム $20 \%$ 水溶液を 0.3 cc および $0.5 \mathrm{cc}$ 添加した場合は, 無添加の場合 より最高温度が約 $2^{\circ} \mathrm{C}$ 低くなつていることがわ かる。温度の上昇は分子量の上昇にほぼ比例する ものと考えられるから，遅延剤として働らいたも のと考えられる。

\section{VI 遅延剤について}

i ステアリン酸は $1 \%$ 以上添加すると顕著な 遅延効果を示す。

ii ステアリン酸鉛はステアリン酸ほど顕著な 遅延効果を示さない。

iii オレイン酸は 1 \%添加すると相当な遅延効 果を示し, ステアリン酸と比較しても $1 \%$ 程度の 添加の場合は大した差はないものと考えられる。

VII 環境温度の影響について
表 81 酢酸マグネシウムの影響

\begin{tabular}{c|c|c|c|c}
\hline \hline $\begin{array}{c}\text { Time } \\
(\mathrm{min})\end{array}$ & Sample & $\begin{array}{c}\mathrm{Mg}(\mathrm{Ac})_{2} \\
0.1 \mathrm{cc}\end{array}$ & $\begin{array}{c}\mathrm{Mg}(\mathrm{Ac})_{2} \\
0.3 \mathrm{cc}\end{array}$ & $\begin{array}{c}\mathrm{Mg}(\mathrm{Ac})_{2} \\
0.5 \mathrm{cc}\end{array}$ \\
\hline 1 & 29.0 & 29.8 & 29.8 & 29.8 \\
2 & 33.8 & 36.5 & 36.0 & 36.8 \\
3 & 37.3 & 39.7 & 38.3 & 39.0 \\
4 & 40.0 & 41.5 & 39.7 & 40.0 \\
5 & 41.6 & 43.0 & 40.8 & 41.0 \\
6 & 42.8 & 43.8 & 41.5 & 41.7 \\
7 & 43.5 & 44.3 & 42.0 & 42.1 \\
8 & 44.1 & 44.8 & 42.3 & 42.4 \\
9 & 44.4 & 45.0 & 42.6 & 42.7 \\
10 & 44.6 & 45.0 & 42.7 & 42.8 \\
11 & 44.7 & 45.0 & 42.8 & 42.9 \\
12 & 44.7 & 45.0 & 42.7 & 42.7 \\
13 & 44.5 & 44.8 & 42.5 & 42.5 \\
14 & 44.2 & 44.6 & 42.2 & 42.2 \\
15 & 44.0 & 44.3 & 42.0 & 42.0 \\
16 & 43.7 & 43.9 & 41.7 & 41.8 \\
17 & 43.2 & 43.4 & 41.3 & 41.4 \\
18 & 42.8 & 43.0 & 39.8 & 41.0 \\
19 & 42.3 & 42.6 & 39.3 & 40.5 \\
20 & 41.9 & 42.2 & 38.8 & 40.1 \\
& & & &
\end{tabular}

室温 $25^{\circ} \mathrm{C}$ 湿度 $72 \%$

$30^{\circ} \mathrm{C}$ までは温度の上昇にともなつて 硬化速度 は順次上昇するが, $35^{\circ} \mathrm{C}$ 付近からは非常に促進 される。したがつて, 硬化速度の調節には印象材 自身の温度を調整する方法が理想的である。

VII $\mathrm{KMnO}_{4}$ を縮合酸化剂とする新しいポリサ ルファイド系の歯科用印象材について

著者が新らしく提案した $\mathrm{KMnO}_{4}$ を縮合酸化 剂とする歯科用印象材の試作品は次の特色を持つ ている。

$\mathrm{i}$ 従来のもののように有害な $\mathrm{PbO}_{2}$ をまつた く混合していないため, 衛生的見地から心配な w。

ii プセジョン可塑度は 1.228 となり, 従来の もの(約 1.1)に比べると非常に優れている。とく にプセジョンかたさ $\mathrm{H}_{1}$ は約 300 を示し, 従来の ものは 170 付近であるから, 弾性はきわめて優秀 であり，しかも残留ひずみ $\mathrm{H}_{2}$ は 50 前後で従来 
のものとほとんど変わらない点からみて寸法の精 度のよいことも期待しうる。

iii 空気中での寸法変化はない。

iv 短時間の浸漬では，水中でも寸法変化はな く，エチルアルコール中でも同様に変化なく，ア ルコールによる消毒も可能で, 市販品には見られ ない特長である。

$\mathrm{v}$ ベンゼン中での寸法変化は通常の市販品と ほぼ同様であるが,これは実用上さしつかえない。

vi 印象の忠実性は $99.982 \%$ で市販品（99.75 〜99.914)より優れている。

vii 狭窄部と最大膨隆部の比が 10:12の金属 の型に送入して硬化時間一変化 $(\%)$ 曲線を作製し た結果, 練和開始後 5 分間で硬化および寸法変化 を終り（従来のもので約 15 分かかる），しかも寸 法変化 $(\%)$ は $0.75 \%$ 以下で市販品 ( $1 \%$ 以上) よ りはるかに優秀である。

viii 臨床実験の結果から印象材として次の適 応性が認められた。

練和は比較的かんたんで臭はほとんどなく，薄 いクリーム色で，印象面は滑らかであり，為害作 用およびアレルギー作用なく，污染および粘着を 起こさず，特に練和開始 5 分間で印象を撤去して も変形は非常にわずかである。

ix 工業的利用について

歯科用印象材の場合は $\mathrm{KMnO}_{4}$ 約 $4 \%$ の使用 で, $20^{\circ} \mathrm{C}$ の場合に, 約 10 分間で硬化を完了さ せることができる点から考えると，現在工業的に 24 時間加硫を行なう場合に，縮合酸化剤として $\mathrm{PbO}_{2}$ は約 $7.5 \%$ ，クメンハイドロパーオキサイ ドは約 $6 \%$ を使用しているのであるから, $\mathrm{KMnO}_{4}$ の縮合能力は抜群であり, はるかに少量の使用で 十分目的を達成できるものと推察され，乙かも性 質のよい生成物をうることが証明されたので，こ の研究を基礎としてその他の工業的応用が生れる ことは必至である。

$$
\text { むすび }
$$

本稿を閉じるK当つて御指導をたまわつた神沢康夫 教授ならびに東節男助教授に厚く謝意を表したい。

\section{参考文献}

1）安田周治：口腔病学会雑誌, Vol. 28, No 3, Part VII. (1961).

2) S. Higashi, "Bulletin, Tokyo Medical Dental University" Vol 6, Part I (1959).

3）安田周治：口腔病学会雑誌，Vol. 28, No 3, Part VI, (1ォ61).

4～6) 安田周治：歯科理工学雑誌, Vol. 2, No 1, P. 58, (1961).

7 8) 安田周治：口腔病学会雑誌, Vol. 28, No 3, part IV, V. (1961).

9) "The Chemistry of Synthetic Resin" II, P. 1169 (1935).

10) J. C. Patrick : Brit. P. 302, 270 (1927).

11) Jean Baer ; Brit. P. 279, 406(1926).

12) India Rubber World, 18, 44 (1938).

13) J. C. Patrick: Ind. Eng. Chem, 28, 1145 (1936).

Trans. Faraday Soc, 32, 347 (1937).

14) J. R. Katz: Trans. Faraday Soc, 32, 77, (1936).

15) C. S. Fuller: Chem, Rev, 143 (1940).

16) J. Donohne, V. Schomaker: J. chem. phys, 16, $92(1948)$.

17) J. E. Beer, M. Carmack: J. Am. chem. Soc, 71, 1215 (1949).

18) H. P. Kock: J. Chem. Soc, 387, 394 (1949).

19）箕浦有二：東京工大学位論文.

20）箕浦有二：日化，73，131(1952).

21）箕浦有二：日化，73，244(1952).

22) Y. Minoura: J. Institute of polytechnics : Osaka City University, 5, C. 206 (1956).

23）箕浦有二：日化， 75，869(1954).

24) K. J. Laidler: "Chemical Kinetics", Mcgraw-Hill Book Co, New York (1950).

25) Thiokol Chemical Corp, March, (1956).

26) 化学便覧 : P. 764.

27） P. J. フローリ：高分子化学, 岡小天, 金丸競 共訳. P. $45(1960)$.

28) P. J. Flory : J. Am. Chem. Soc, 63, 3083, (1941).

29) P. J. Flory: Chem. Revs, 39, 137 (1946).

30) R. H. Kienle, P. A. Van der Meulen, F. E. Petke: J. Am. Chem. Soc, 61, 2258, 2268 (1939).

31) R. H. Kienle, F. E. Patke : ibid, 62, 1053, (1940), 63, 481 (1941).

32) R. Signer, P. Tavel : Helv. Chim. Acta, 26, $1972(1943)$.

33) I. Jullander, B. Blorn-Sallin : J. Polymer Soc, 3, 804 (1948).

34) D. B. Fordyce, J. D. Ferry : J. Am. Chem. Soc 73, 62 (1951). 